\title{
A new hemiarthrine bopyrid, Izuohshimaphryxus hoshinoi (Crustacea: Isopoda) from Izu-Ohshima Island, Sagami Sea, Pacific coast of central Japan
}

Nobuhiro Saito

\begin{abstract}
Izuohshimaphryxus hoshinoi, a new genus and species of hemiarthrine bopyrid, is described on the basis of a single female specimen from the coastal waters of Izu-Ohshima Island, Sagami Sea, Pacific coast of central Japan. This bopyrid infests an anthozoan-associated shrimp, Ancylomenes speciosus (Okuno, 2004), attaching to the dorsal surface of the pleon. This new genus is most similar to Filophryxus Bruce, 1972 but is distinguished by a) the presence of pereopods on the concave side, b) number of lateral plates of the pleon, and c) absence of a pleotelson. This is the third identified species known to attach to the dorsal surface of the pleon of a caridean shrimp host.
\end{abstract}

Key words: Bopyridae, new genus and species, anthozoan-associated shrimp, Ancylomenes speciosus

\section{Introduction}

Hemiarthrinae Markham, 1972 is a subfamily of highly modified bopyrid isopods that occur on the pleon of marine caridean shrimps (Bruce, 1965, 1972; Markham, 1972). Fiftyseven species in 27 genera have been recorded (Boyko, 2015; Saito \& Shimomura, 2015), and 14 species, including four unidentified species, are known from Japanese waters (Saito et al., 2000; Shimomura et al., 2006; Komai \& Minemizu, 2014; Miura, 2014; Saito \& Shimomura, 2015). Most of these Japanese hemiarthrine bopyrids, aside from two unidentified species, attach to the ventral surface of caridean shrimps belonging to five families (Palaemonidae, Alpheidae, Hippolytidae, Rhynchocinetidae, and Pandalidae) (Saito, 2002; Saito \& Shimomura, 2015). Recently, two specimens of an anthozoan-associated shrimp, Ancylomenes speciosus (Okuno, 2004), each bearing one hemiarthrine bopyrid on the dorsal surface of the pleon, were collected by SCUBA diving off
Izu-Ohshima Island, Sagami Sea, Pacific coast of central Japan. One of the bopyrids was lost when it became detached from its host. Here I describe a new hemiarthrine species based on the remaining specimen and propose a new genus for this new species. This find represents the third species of identified bopyrid confirmed to attach to the dorsal surface of the pleon of a caridean shrimp host.

Abbreviations used: BL, body length of the bopyrid, measured along the major axis of the body from the tip of the head to the posterior end of the brood pouch; CL, carapace length of the host shrimp, measured from the posterior margin of the orbit to the midpoint of the posterodorsal margin of the carapace. Other measurements and terminology follow Markham (1985) for the bopyrid and Hayashi (2007) for the host shrimp. The holotype of the new bopyrid isopod and the examined specimens of the host shrimp species are deposited in the Kitakyushu Museum of Natural History and Human History (KMNH IvR), Kitakyushu, Ja- 
pan.

\section{Taxonomic Account}

Family Bopyridae Rafinesque, 1815

Subfamily Hemiarthrinae Markham, 1972

Genus Izuohshimaphryxus gen. nov. http://zoobank.org:pub:27DFA32D-50C5-4E 13-9993-2CD5FF80FDE3

\section{Diagnosis}

Female: lateral sides of head produced into expanded lobes. All seven pereomeres distinct marginally on concave side; pereomere 1 distinct on dorsal surface; pereomeres $1-6$ on concave side and pereomere 1 on convex side with accessory extensions. Pleomeres fused completely; pleotelson absent. All seven and first two pereopods present on concave and convex sides of pereon, respectively; four and three uniramous lateral plates present on concave and convex sides of pleon, respectively; pleopods and uropods absent. Male unknown.

\section{Type Species}

Izuohshimaphryxus hoshinoi sp. nov., by original designation.

\section{Etymology}

The generic name refers to Izu-Ohshima Island, the type locality of the new bopyrid, which is added to the generic stem-phryxus.

\section{Remarks}

In the female, the numbers of pereopods (seven and two) and lateral plates (four and three) on each side of the body, and the lack of pleopods, pleotelson, and uropods readily distinguish Izuohshimaphryxus from the other genera of Hemiarthrinae [cf. characters of other congeners of Hemiarthrinae represented by Miura (2014)].

The expanded lobes on the sides of the head and the accessory extensions (called filiform coxal plates by Bruce, 1972) on the pereomeres in the female holotype support a close relationship with Filophryxus Bruce, 1972, which is only known from its type species, Filophryxus dorsalis Bruce, 1972, found attached to the dorsal surface of Periclimenes hertwigi Balss, 1913 and Periclimenes uniunguiculatus Bruce, 1990 (Caridea, Palaemonidae) in Queensland and New Caledonia, respectively (Bruce, 1972, 1990). These characters are not seen in other species in the subfamily. However, Filophryxus has only six pereopods (not seven) on the concave side, four pairs of lateral plates [misinterpreted as pleopods by Bruce (1972)] on the pleon (instead of three on one side and four on the other), and the pleotelson is present (versus absent in the new genus).

Izuohshimaphryxus hoshinoi sp. nov. http://zoobank.org/act:662B05E5-5CA3-48 ED-A716-2E9A8132AE98

(Figs. 1-2)

[New Japanese name: Akahoshikakure-nokoshiyadori]

\section{Material examined}

Holotype: KMNH IvR 500,807, female (BL $3.03 \mathrm{~mm})$, “Aki-no-hama" Point $\left(34^{\circ} 47^{\prime} 14^{\prime \prime} \mathrm{N}\right.$, $139^{\circ} 24^{\prime} 44^{\prime \prime} \mathrm{E}$ ), northeastern coast of Izu-Ohshima Island, 1 June 2013, $20 \mathrm{~m}$ deep, removed from dorsal surface of pleon of a shrimp, Ancylomenes speciosus, male (CL $4.93 \mathrm{~mm}$ ), associated with the sea anemone Antheopsis maculata (Klunzinger, 1877) sensu Uchida \& Soyama (2001), coll. O. Hoshino.

\section{Description of holotype female}

Body (Fig. 1A, B) markedly asymmetrical, greatly expanded on convex (left) side, suboval in general outline; body axis distortion about $40^{\circ}$; body width at broadest part of brood pouch about 0.7 times greater than body length.

Head (Fig. 1B) completely embedded in pereon; frontal margin nearly straight. Expanded 

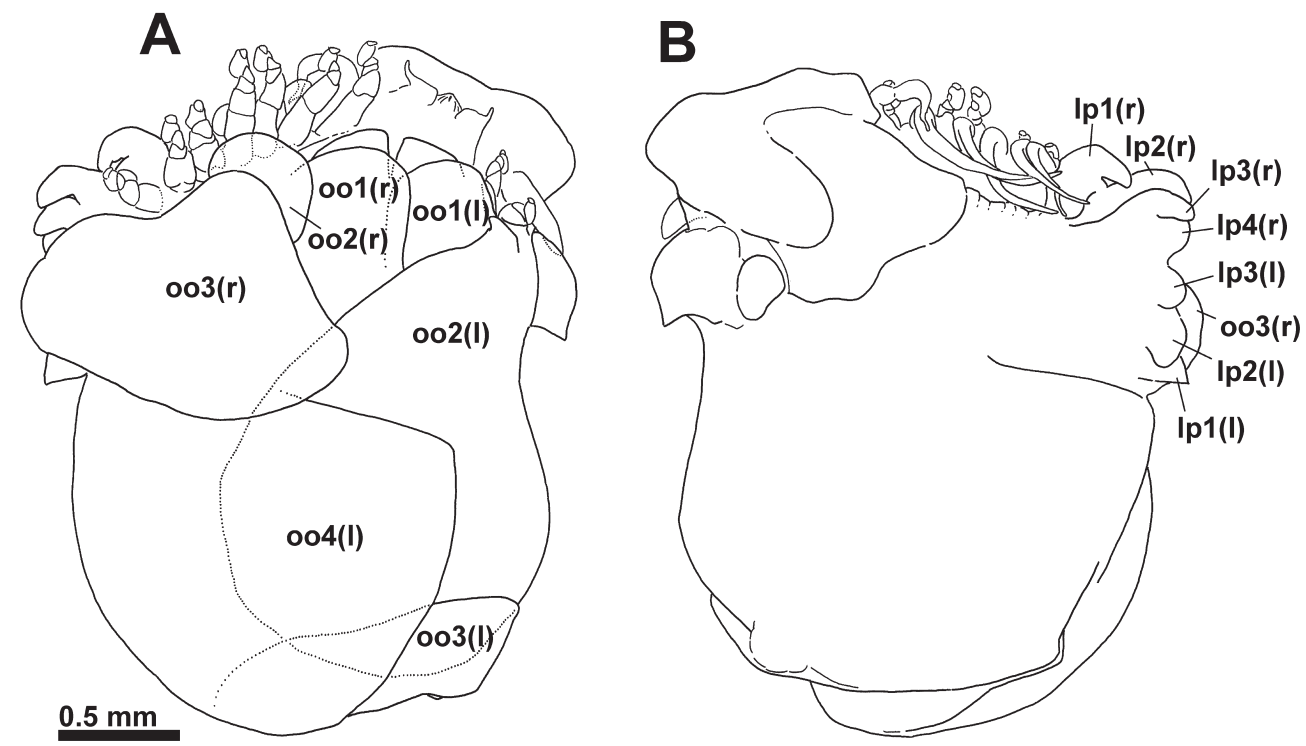

Fig. 1. Izuohshimaphryxus hoshinoi sp. nov., holotype, female (BL $3.03 \mathrm{~mm}$ ), KMNH IvR 500,807, northeastern coast of IzuOhshima Island, Sagami Sea, Japan, 20 m depth. A, ventral view; B, dorsal view. Abbreviations: 1p-1-4, lateral plates 1-4; oo-1-4, oostegites 1-4; (1), left (= convex side); (r), right (= concave side).

lobe of convex side well developed, concave (right) side rather small. Eyes absent.

Antenna 1 (Fig. 1A) absent.

Antenna 2 (Fig. 2A) peduncle laminar; flagellum fused with peduncle, not segmented; lacking setae.

Maxilliped (Fig. 2B, C) semi-ovoid, nearly straight medially, roundly angled anteriorly, lacking palp but short prominent spur present; anterior article about 2.4 times as long as posterior article.

Barbula (Fig. 2D) with two pairs of short, stout lateral projections.

Pereon (Fig. 1B) pereomere 1 of convex side expressed as dorsolateral boss accompanied by coxal plate with expanded acute posterior-lateral point.

Accessory extensions of concave side (Fig. 1B) elongate; convex side stout (Fig. 2E).

Brood pouch (Fig. 1A) enclosed mainly by oostegites 2-4 of convex side, expanded far laterally; each oostegite separate. Oostegite 1 of concave side (Fig. 2F) approximately oval, not segmented, produced into posterior-lateral lobe; convex side (Fig. 2G) sub-rectangular.

Pereopods complete, without fusion of articles (Fig. 2H, I); basis rectangular; ischium rectangular, shorter than basis; merus trapezoidal, with short stout setae on inferior margin; carpus triangular, with stout setae on inferior margin; propodus ovate; dactylus stout.

Pleon (Fig. 1A, B) smooth, without ventral tubercles.

Lateral plates (Fig. 1B) small, lobe-shaped; those on convex side smaller than those concave side.

\section{Ecological note}

The female of Izuohshimaphryxus hoshinoi sp. nov. was found on an anthozoan-associated shrimp, Ancylomenes speciosus (Fig. 3). The bopyrid was attached by its dorsal side to the dorsal surface of the second pleonite of the host, with half of the bopyrid body inserted into the first pleonite of the shrimp. The bopyrid faced anteriorly on the host. Pleonite 1 of the host shrimp was expanded to form a fold around approximately half of the bopyrid's 

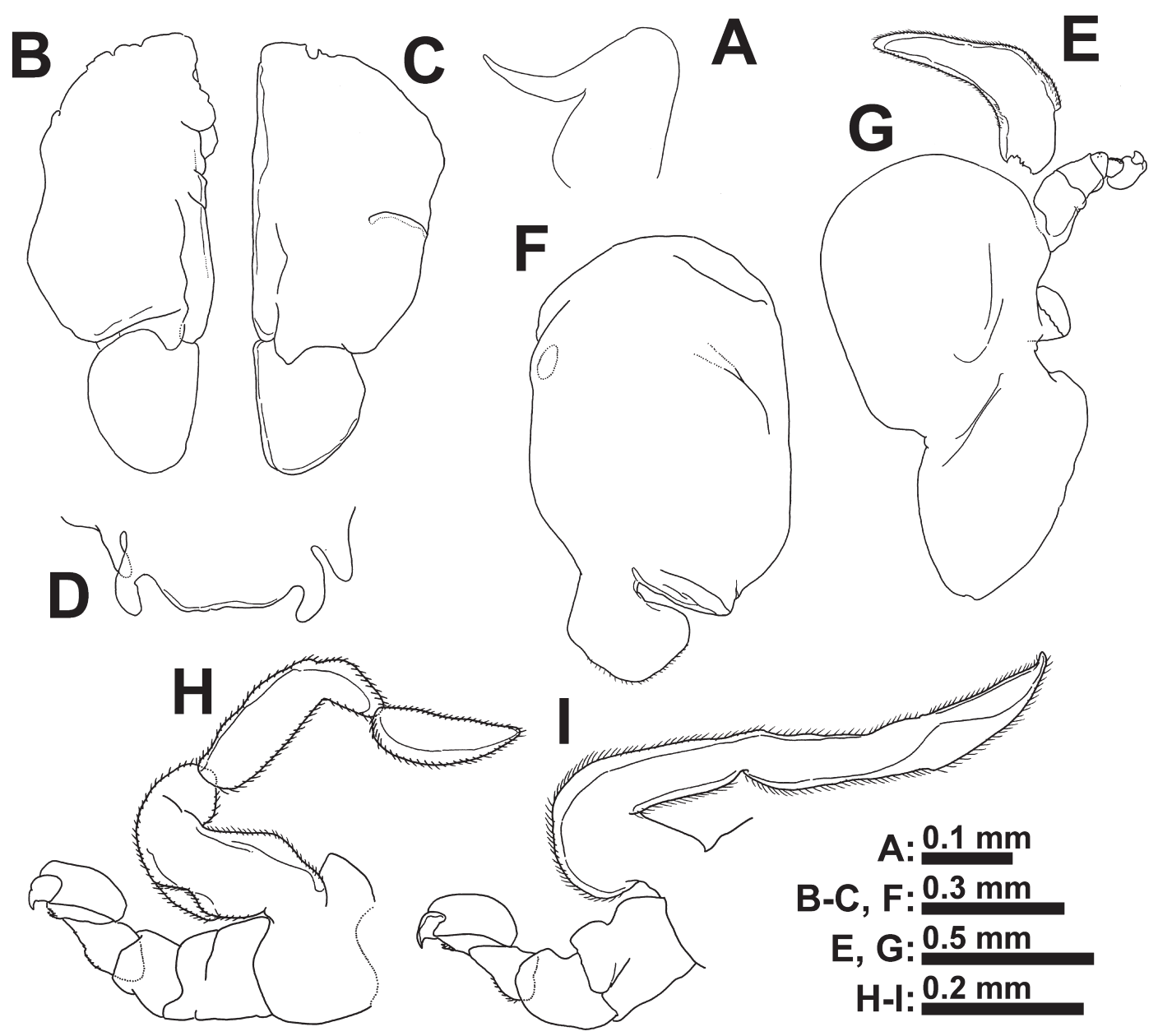

$\mathrm{H}-\mathrm{I}: 0.2 \mathrm{~mm}$

Fig. 2. Izuohshimaphryxus hoshinoi sp. nov., holotype, female (BL $3.03 \mathrm{~mm}$ ), KMNH IvR 500,807. A, right antenna 2, ventral view; $\mathrm{B}$, right maxilliped, ventral view; C, left maxilliped, ventral view; D, barbula, ventral view; E, accessory extension of left pereonite 1, ventral view; F, right oostegite 1, ventral view; G, left oostegite 1, ventral view; H, right pereopod 1, medial view; I, right pereopod 2, medial view.

body. Thus, the presence of the bopyrid was very easy to recognize, even in the field. The host shrimp, A. speciosus, is associated with the sea anemone Antheopsis maculata. Two of 21 shrimps found in the field appeared to be infested by I. hoshinoi (Osamu Hoshino pers. comm.). One of the bopyrids fell off the host and could not be confirmed, but assuming it was also I. hoshinoi, the prevalence of the bopyrids was $9.5 \%$. The shrimp with the missing bopyrid (KMNH IvR 500,808) is a male (CL $3.80 \mathrm{~mm}$ ); the body colour of the host shrimp (CL $4.93 \mathrm{~mm}$ ) of the holotype of $I$. hoshinoi was typical of that of mature males (cf. Okuno, 2004), but this specimen did not have an appendix masculina on the endopod of the second pleopod.

\section{Distribution}

Known only from Izu-Ohshima Island, Sagami Sea, Pacific coast of central Japan, $20 \mathrm{~m}$ depth. 


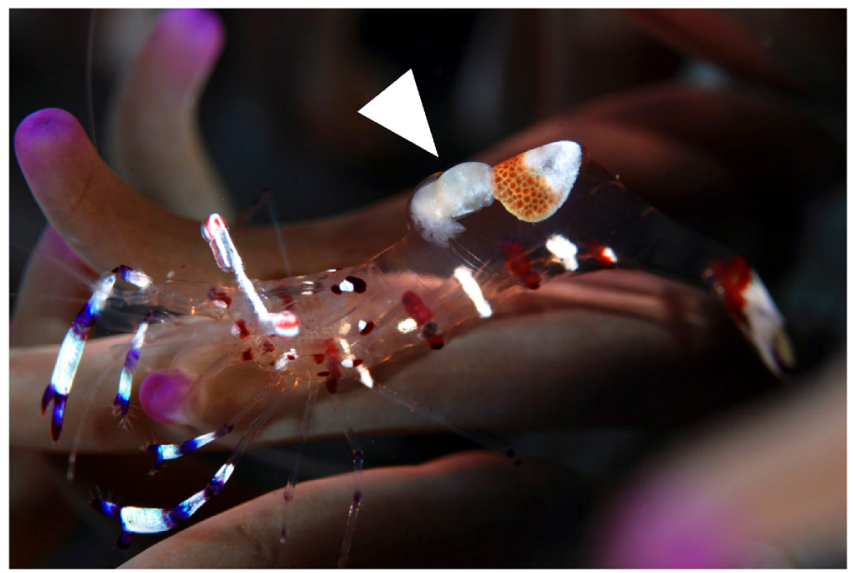

Fig. 3. Ancylomenes speciosus (Okuno, 2004), male (CL $4.93 \mathrm{~mm}$ ), host shrimp of Izuohshimaphryxus hoshinoi sp. nov., associated with the sea anemone Antheopsis maculata (Klunzinger, 1877) sensu Uchida \& Soyama (2001), northeastern coast of Izu-Ohshima Island, Sagami Sea, Japan, $20 \mathrm{~m}$ depth, habitus in situ, photo by O. Hoshino. Arrow indicates holotype of I. hoshinoi sp. nov., attached to dorsal surface of second pleonite of host, with half of its body inserted in shrimp's first pleonite.

\section{Etymology}

The specific name is the Latin genitive hoshinoi selected to honor the collector of the type-material, Mr. Osamu Hoshino, a professional diver on Izu-Ohshima Island, Tokyo, in recognition of his contributions to the knowledge of the marine fauna of that island.

\section{Remarks}

The occurrence of hemiarthrine bopyrids on the dorsal surface of the pleon of hosts is rare, as they occur predominantly on the ventral surface of marine caridean shrimps (Bruce, 1965, 1972; Markham, 1990, 2010). Izuohshimaphryxus hoshinoi sp. nov., Metaphrixus intutus Bruce, 1965 (infesting Palaemonella and Periclimenes in Zanzibar (type locality), Singapore, and Australia) (Bruce, 1965; Markham, 2010) and Filophryxus dorsalis Bruce, 1972 (see above for details) are the only species known thus far to infest the dorsal surface of their hosts.

Izuohshimaphryxus hoshinoi sp. nov. is attached to the second pleonite and inserted into the first pleonite of its host shrimp Ancylomenes speciosus, but $M$. intutus and F. dorsalis were attached at other positions on the dor- sal surfaces of their hosts, viz., the first and fourth pleonites, respectively. It should be noted that Miura (2014) and Komai \& Minemizu (2014) found two bopyrids, Mesophryxus sp. and an unidentified isopod, attached to the dorsal surface of the Japanese caridean shrimps Periclimenes commensalis Borradaile, 1915 from Kagoshima Bay, Kagoshima Prefecture, and Eupontonia gracilipes Komai \& Minemizu, 2014 from Ishigaki Island, Ryukyu Islands, Okinawa Prefecture, respectively. These bopyrids have been not identified to the species level and require further examination and recollection.

\section{Acknowledgments}

I am deeply grateful to Mr. Osamu Hoshino (Diving Service Chap, Izu-Ohshima, Tokyo) for providing the materials used in this study; Drs. Junji Okuno and Kensuke Yanagi (Coastal Branch of Natural History Museum and Institute, Chiba) for helping to identity of the host shrimp and the sea anemone, respectively; and Drs. Michitaka Shimomura (Kitakyushu Museum of Natural History and Human History, Fukuoka) and Kazuyoshi Hashizume (Toita 
Women's College, Tokyo) for supplying some necessary literature. I sincerely thank Drs. Jason D. Williams (Hofstra University, Hempstead, New York) and Mark J. Grygier (Lake Biwa Museum, Siga) for making helpful suggestions concerning early drafts of this paper. Thanks are also extended to Dr. Akira Asakura (Seto Marine Biological Laboratory, Field Science Education and Research Center, Kyoto University) and two anonymous reviewers for their reviewing this manuscript.

\section{$\square$ Literature Cited}

Boyko, C. B., 2015. Hemiarthrinae Markham, 1972. In: M. Schotte, C. B. Boyko, N. L. Bruce, G. C. B. Poore, S. Taiti, \& G. D. F. Wilson, (eds.), World Marine, Freshwater and Terrestrial Isopod Crustaceans Database. Accessed through: World Register of Marine Species at http://www.marinespecies.org/ aphia.php? $\mathrm{p}=$ taxdetails\&id $=589331$ on 2015-07-23.

Bruce, A. J., 1965. An interesting new phryxid (Epicaridea) parasitic on a pontoniinid shrimp. Annals and Magazine of Natural History, Ser. 13, 8: 285-390.

Bruce, A. J., 1972. Filophryxus dorsalis gen. nov., sp. nov., an unusual bopyrid parasite from eastern Australia. Parasitology, 65: 351-358.

Bruce, A. J., 1990. Crustacea Decapoda: Deepsea palaemonid shrimps from New Caledonian waters. In: A. Crosnier, (ed.), Résultats des Campagnes MUSORSTOM, vol. 6. Mémoires du Muséum national d'Histoire naturelle, Sér. A (Zoologie), 145: 149-215.

Hayashi, K., 2007. Caridean Shrimps (Crustacea: Decapoda: Pleocyemata) from Japanese Waters Part 1. xiv + 292 pp. Seibutsu Kenkyusha, Tokyo. (In Japanese)

Komai, T., \& Minemizu, R., 2014. A new species of the pontoniine shrimp genus Eupontonia (Crustacea: Decapoda: Caridea: Palaemonidae) from the Ryukyu Islands, Japan. Zootaxa, 3784(2): 171-178.
Markham, J. C., 1972. Two new genera of western Atlantic abdominally parasitizing Bopyridae (Isopoda, Epicaridea), with a proposed new name for their subfamily. Crustaceana Supplement, 3: 39-56.

Markham, J. C., 1985. A review of the bopyrid isopods infesting caridean shrimps in the northwestern Atlantic Ocean, with special reference to those collected during the Hourglass cruises in the Gulf of Mexico. Memoirs of the Hourglass Cruises, 7(3): 1-156.

Markham, J. C., 1990. Crustacea Isopoda: new records of Bopyridae from New Caledonian waters. In: A. Crosnier (ed.), Résultats des Campagnes MUSORSTOM, vol. 6. Mémoires du Muséum national d'Histoire naturelle, Sér. A (Zoologie), 145: 55-69.

Markham, J. C., 2010. The isopod parasites (Crustacea: Isopoda: Bopyridae) of decapod Crustacea of Queensland, Australia, with descriptions of three new species. In: P. J. F. Davie, \& J. A. Phillips (eds.), Proceedings of the Thirteenth International Marine Biological Workshop, The Marine Fauna and Flora of Moreton Bay, Queensland. Memoirs of the Queensland Museum (Nature), 54(3): 151-197.

Miura, T., 2014. Note on a parasitic isopod (Bopyridae; Hemiarthrinae) on a crinoid-associated shrimp, Periclimenes commensalis, living on Oxycomanthus japonicas found in Kagoshima Bay. Nature of Kagoshima, 40: 101-106. (In Japanese)

Okuno, J., 2004. Periclimenes speciosus, a new species of anthozoan associated shrimp (Crustacea: Decapoda: Palaemonidae) from southern Japan. Zoological Science, 21: 865-875.

Saito, N., 2002. A list of crustacean hosts of the epicaridean isopods (Crustacea: Peracarida) in the Japanese waters. Taxa (Proceedings of the Japanese Society of Systematic Zoology), 13: 18-31. (In Japanese with English abstract)

Saito, N., Itani, G., \& Nunomura, N., 2000. A preliminary check list of isopod crustaceans 
in Japan. Bulletin of the Toyama Science Museum, 23: 11-107. (In Japanese with English abstract)

Saito, N., \& Shimomura, M., 2015. A new abdominally parasitizing bopyrid, Anisarthrus okunoi sp. nov. (Crustacea: Isopoda), infecting a hinge-beak shrimp Rhynchocinetes uritai Kubo, 1942 (Crustacea: Decapoda: Rhynchocinetidae). Species Diversity, 20: 37-43.

Shimomura, M., Ohtsuka, S., \& Sakakihara, T., 2006. Two bopyrid isopods infesting caridean shrimp Hippolyte sp. in the Seto Inland Sea, western Japan (Crustacea: Peracarida). Bulletin of the Kitakyushu Museum of Natu- ral History and Human History, Series A (Natural History), 4: 1-7.

Uchida, H., \& Soyama, I., 2001. Sea Anemones in Japanese waters. 157 pp. TBS Britannica, Tokyo. (In Japanese)

\section{Address}

(NS) Suido-sha Co. Ltd., Ikuta 8-11-11, Tamaku, Kawasaki, Kanagawa 214-0038, Japan

\section{E-mail address}

(NS) nsaitoh@suidosha.co.jp 